\title{
An Insight into SBM Efficiency of Slovak Commercial Banks
}

\author{
Martin Bod'a', Emília Zimková \\ ${ }^{1}$ Matej Bel University in Banská Bystrica \\ Faculty of Economics, Department of Quantitative Methods and Information Systems \\ Tajovského 10, 97590 Banská Bystrica, the Slovak Republic \\ E-mail: martin.boda@umb.sk \\ 2 Matej Bel University in Banská Bystrica \\ Faculty of Economics, Department of Finance and Accounting \\ Tajovského 10, 97590 Banská Bystrica, the Slovak Republic \\ E-mail: emilia.zimkova@umb.sk
}

\begin{abstract}
The paper investigates into the efficiency of the Slovak banking industry over the years 2000-2011 through the prism of the profit approach to the perception of efficiency of commercial banks. More precisely, the aim of the paper is to benchmark individual commercial banks with respect to their efficiency status under the profit definition of efficiency. Nonetheless, massive structural changes that took place in the Slovak economy also affected significantly the development of the Slovak banking sector and gave rise to shifts in its production function. In order to include these qualitative changes into consideration, the entire period of 12 years was - on economic grounds - divided into three consecutive non-overlapping sub-periods (2000-2003, 2004-2008, 2009-2011) during which the production function may be viewed stable and free of qualitative alterations. A panel of 11 organizational units (i.e. commercial banks) of the Slovak banking sector was identified, and under the assumption of the production function being constant and shiftless in the three sub-periods the data on them were pooled together for each of the three sub-periods. In evaluating their technical efficiency in the individual three sub-periods, a non-parametric method of evaluation is employed based on the slack-based measure (SBM) model of data envelopment analysis. During the period of 12 years examined, Slovenská sporitel'ña maintained a comparatively high SBM technical efficiency and other Slovak banks were subject to positive or negative changes in their comparative efficiency profile. The paper further demonstrates how this information can be used outside the academic sphere with an accent laid upon the stockholders and the management of the commercial banks under investigation.
\end{abstract}

Keywords: efficiency, the Slovak banking industry, SBM model, the profit approach

JEL codes: G21, C44 


\section{Introduction}

Over recent years, the topic of measuring efficiency of commercial banks has experienced massive upheaval. Three principal approaches have been developed (to say nothing of their modifications) and are used intensively in evaluating efficiency of commercial banks. Out of these approaches, viz. the service-oriented approach, the intermediation approach and the profit approach, exclusive attention in the paper is given to the profit approach as the basal "commercial" standpoint under which Slovak banks operate striving after a high profit margin for their owners. The task of efficiency evaluation necessitates the assumption of the existence of a production function in the banking industry (which links the inputs and outputs of banks and determines the shape of the production frontier) and efficiency calculations then often base on measuring the distance of individual commercial banks from the production frontier embodied in the production function. The framework under which the production function is specified can be either parametric, non-parametric or semi-parametric. Whereas the parametric method restricts the production function to a certain parametric form which is then estimated, the non-parametric method avoids the formulation of a parametric production function and constructs on some well-understood economic principles the production possibility set. One of these principles is expressed in the technical scalability of operations, to wit, in the specification of the character of returns to scale under which the banking industry operates.

In the paper, the non-parametric slack-based measure (SBM) model is applied with the profit approach of interpreting the bank's efficiency to a data set of eleven organisational units ${ }^{1}$ of the Slovak banking industry for the period of the years 2000-2011. During this period, the Slovak banking sector has gone through some changes as to its structure, competitiveness and regulation. Nonetheless, three periodization landmarks were identified and catalogued, between which it is assumed that the production function did not change and remained intact, i.e. was invariant with respect to a time shift. The three landmarks divided the entire period of twelve years into three sub-periods (2000-2003, 2004-2008, 20092011), over which the data on individual organizational units of the Slovak banking industry were pooled for their joint evaluation. Between these three subperiods a possible qualitative change of the production function is both possible and most probable. In each sub-period, individual organisational units were evaluated and their efficiency was determined by the slack-based measure. This procedure permits to fulfil the aim of the paper, which is to benchmark individual Slovak commercial banks with respect to their efficiency status under the profit approach.

\footnotetext{
${ }^{1}$ Note that the term "organisational unit" is more appropriate here as some of the banks fused or merged during the evaluated period.
} 
The paper is organized in 5 sections, the first of which is introductory and the last is concluding. The second section explains the profit approach for measuring efficiency of commercial banks and provides, in a condensed way, an overview of some relevant studies on the topic. The third methodological section is accompanied by the fourth section which instructs on the data, presents the results and includes their interpretation.

\section{Conceptual issues and an overview of the literature}

Conceptual views of efficiency of commercial banks differ. Individual theoretical concepts concur that commercial banks are agents of a transformation process and that during this process they transmute a set of inputs into a set of outputs. These inputs and outputs are linked in operations of commercial banks through a production function, which specifies the maximum attainable outputs at the given level of inputs. On the one hand, there is an explicit or implicit agreement that such a functional relationship exists; on the other hand, there is no general agreement on the production function of commercial banks which would reflect the aims that commercial banks seek to pursue.

So far three main approaches have been developed and used both in theory and practice, and these are the intermediation approach, the service-oriented approach and the profit approach. The primary source of difference between them is the treatment of deposits, which have both input and output characteristics. Only the newest of these approaches, the profit approach, is clarified in the next paragraph since only this approach is topical for the paper.

The profit approach was introduced by Berger and Mester (2003). They investigated cost and profit productivity of the US banking industry. They found out that during the period from 1991 to 1997 cost productivity worsened whereas profit productivity improved substantially. They concluded that banks had been offering a wider range of financial services providing additional convenience, which may have raised costs but also raised revenues by more than the cost increase. Since this approach is relatively new, there is no consensus as to whether these positions hold. Studies which would account for possible impact of the financial crisis on efficiency of commercial banks prepared under this approach were not yet published. The foregoing research of the profit approach was the value-added approach, which considers that both liability and assets categories possess some output characteristics. Only those categories which contribute to a substantial value added are treated as outputs whilst the others are treated as either inputs or intermediate products depending on the specific attributes of each category. This approach was promoted by Berger, Hanweck and Humphrey (1987), and Berger and Humphrey (1997).

The most commonly used approach in the banking industry is probably the intermediation approach but this approach does not account for the strong profit orientation that is present and perceptible in commercial operations of the Slovak 
banking sector. The negligence of other approaches in empirical research leaves some room for a thorough application of the profit approach and even calls for it.

There has been intensive research on measuring efficiency of commercial banks and their benchmarking. It is probably not possible to give an exhaustive overview of the relevant literature on this topic. In consequence of this, the scope of the presentation here is limited only to research that focused on the Visegrad Group countries (the Czech Republic, Poland, Hungary and the Slovak Republic, in alphabetical order) and utilized the non-parametric approach of the data envelopment analysis (DEA). Table 1 summarizes empirical studies that are germane to this topic and lists especially those studies that have applied the nonparametric approach based on a DEA model. The list of research works is structured into two categories: cross-country studies (which investigated the efficiency of commercial banks across several countries for the purpose of comparison) and single market studies (which focused on the efficiency of commercial banks in one country only).

Table 1 Empirical studies grouped by the Visegrad Group coverage (in alphabetical order)

\begin{tabular}{lc}
\hline \multicolumn{1}{c}{ Cross-country studies } & DEA methodology \\
\hline \hline Grigorian and Manole (2002) & CCR, BCC \\
\hline Kenjegalieva et al (2009) & BCC \\
\hline Stavárek (2006) & CCR, BCC \\
\hline Tomova (2006) & BCC \\
\hline Vincova (2006) & CCR, BCC \\
\hline Anayiotos et al. (2010) & CCR \\
\hline
\end{tabular}

\begin{tabular}{lc}
\hline \hline \multicolumn{1}{c}{ Single market studies } & DEA methodology \\
\hline \hline Stavárek and Řepková (2012) & CCR, BCC \\
\hline Wozniewska (2008) & CCR, BCC \\
\hline Zemanová (2007) & CCR \\
\hline
\end{tabular}

Source: The relevant authors

Although the majority of the studies (amongst the cited authors: Grigorian and Manole, 2002; Tomova, 2006; Řepková and Stavárek, 2012; Kenjegalieva et al., 2009) fell back upon both nonparametric and parametric techniques to evaluate the bank performance in terms of efficiency, all of the studies that are listed in Table 1 utilized in their quest only basic and rudimentary DEA models, the model by Charnes, Cooper and Rhodes addressed conventionally as the CCR model and the model by Banker, Charnes and Cooper addressed conventionally as the BCC model. In this paper, the model by Tone, a more advanced DEA model, is utilized and this model is usually called the SBM (slack-based measure) model. 


\section{Methodology}

In order to determine the technical efficiency of organizational units of the Slovak banking sector under the profit approach, the SBM analysis was applied on the panel data of eleven organizational units of the Slovak banking sector during the period from 2000 to 2011. (This data span is chosen in regard to the data availability and currency for the needs of this analysis.) The methodological procedure stands on several characteristic points or assumptions that underlie and shape the line of research and they are summarized and explained in brief in the following text. This section begins with a short but essential exposition of the non-parametric SBM model and continues with an explanation how this model was used in evaluating technical efficiency of Slovak commercial banks. On top of this, three periods in the development of the Slovak banking sector were distinguished and this division was justified.

\section{The employment of the SBM model}

In this paper, the assumption of variable returns to scale is formed (which, of course includes a specific case of constant returns to scale) and combined with a non-oriented SBM model in evaluating the organizational units of the Slovak banking sector on a comparative basis. Note that the studies enumerated earlier used in their analysis the rudimentary CCR or BCC model. This study thus goes farther.

In the exact formulation of the SBM model, it is assumed that the data on $n$ production units are available, where any production unit $o, o \in\{1, \ldots, n\}$, produces $s$ desirable outputs out of $m$ inputs. The values of inputs of production unit $o$ are represented by vector $\mathbf{x}_{o}=\left(x_{01}, \ldots, x_{o m}\right)^{\prime}$ and the values of outputs by vector $\mathbf{y}_{o}=\left(y_{o 1}, \ldots, y_{o s}\right)^{\prime}$. The elements of both vectors are positive. Individual inputs and outputs have corresponding vectors of potential slacks $\mathbf{s}^{\mathbf{x}}{ }_{o}=\left(s^{\mathbf{x}}{ }_{o 1}, \ldots, s_{o m}^{\mathbf{x}}\right)^{\prime}$ and $\mathbf{s}^{\mathbf{y}}{ }_{o}=\left(s^{\mathbf{y}}{ }_{o 1}, \ldots, s^{\mathbf{y}}{ }_{o s}\right)^{\prime}$, which states how individual inputs and outputs must be improved in order that production unit o become efficient (whereas vector of inputs $\mathbf{x}_{0}$ need be reduced by $\mathbf{s}^{\mathbf{x}}{ }_{o}$ and vector of outputs $\mathbf{y}_{o}$ need be increased by $\mathbf{s}^{\mathbf{y}}{ }_{0}$ ). These slacks are to be identified by the DEA and serve as an exclusive basis of efficiency calculation for respective production unit 0 .

For each production unit $o, o \in\{1, \ldots, n\}$, it is necessary to solve the following task of optimal programming of the non-oriented SBM model under the assumption of variable returns to scale,

$\rho_{o}\left(\lambda, \mathbf{s}^{\mathbf{x}}, \mathbf{s}^{\mathbf{y}}\right)=\frac{1-\frac{1}{m} \sum_{i=1}^{i=m} s_{o i}^{\mathbf{x}} / x_{o i}}{1+\frac{1}{s} \sum_{j=1}^{j=s} s_{o j}^{\mathbf{y}} / y_{o j}}=! \min$

$$
\begin{array}{ll} 
& \mathbf{s}^{\mathbf{x}}=\mathbf{x}_{o}-\sum_{i=1}^{i=n}\{\lambda\}_{i} \mathbf{x}_{i} \geq \mathbf{0} \\
\text { with respect to } & \mathbf{s}^{\mathbf{y}}=\mathbf{y}_{o}-\sum_{i=1}^{i=n}\{\lambda\}_{i} \mathbf{y}_{i} \geq \mathbf{0} \\
& \sum_{i=1}^{i=n}\{\lambda\}_{i}=1, \lambda \geq \mathbf{0}
\end{array}
$$


The symbol " $\geq "$ denotes at a vector that respective elements of this vector are non-negative and at least one element is non-zero.

The restrictions of the optimization task constructs the production possibility set with respect to $n$ production units and their observed inputs $\mathbf{x}_{1}, \ldots, \mathbf{x}_{n}$ and outputs $\mathbf{y}_{1}, \ldots, \mathbf{y}_{n}$ as well as their convex linear combinations in $\Re^{m}$ and $\Re^{s}$ respectively. The coefficient $\rho$ takes values at interval $[0,1]$ and it is the SBM score of technical efficiency (in this case of production unit $O$ whose task (1) is subject to optimization. If for some production unit $\rho=1$ happens to be the case, this production unit is called SBM-efficient, which means that it is technically efficient in the sample of $n$ production units to be evaluated. Although it may not seem prima facie, this score is very intuitive and easily interpretable. Furthermore, it is easy to explicate the rationale of the slack-based measure of technical efficiency. Whereas each production unit transmutes in its operations a set of inputs into a set of outputs, this operation need not be inevitably technically efficient. It sometimes may happen that the production of given outputs is possible with lower amounts of inputs, or, otherwise, at the consumption of given levels of inputs the production unit may attain a higher level of outputs. In such a case, the production process is characteristic of slack on the side of inputs and/or outputs. Technical inefficiency on the side of inputs is captured by the fraction

technical inefficiency of an input $=\frac{\text { real input }- \text { identified slack }}{\text { real input }}$,

whose values are restricted to interval $[0,1]$. If the production unit is technically efficient in the given input, the program in (1) identifies a zero slack and the indicator in (2) is evaluated at 1 . Similarly, technical inefficiency on the side of outputs may be naturally described by the expression

technical inefficiency of an output $=\frac{\text { real output }+ \text { identified slack }}{\text { real output }}$,

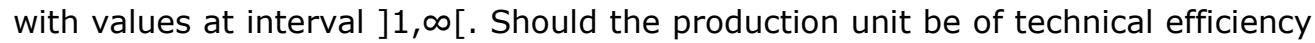
in the given output, the corresponding slack is by the program in (1) is identified zero and the indicator in (3) would attain the value of 1 . The SBM score $\rho$ in (1) may be clearly manipulated into

$$
\rho_{o}=\frac{\frac{1}{m} \sum_{i=1}^{i=m}\left(x_{o i}-s_{o i}^{\mathbf{x}}\right) / x_{o i}}{\frac{1}{s} \sum_{j=1}^{j=s}\left(y_{o j}+s_{o j}^{\mathbf{y}}\right) / y_{o j}}=\frac{\text { average technical inefficiency of inputs }}{\text { average technical inefficiency of outputs }} .
$$

Indisputably, if the production unit exhibits technical inefficiency even with one input, the nominator is lower than 1 , and if it happens to be technically inefficient at least with one output, the denominator has to be greater than 1 . This property 
implies that the SBM score (4) is 1 if and only if the production unit is fully technically efficient (and both the nominator and the denominator equal one). On the other hand, for a technically inefficient production unit, the SBM score in (4) is lower than 1 . In general, the SBM score $\rho$ has values at interval $[0,1]$.

The reader may familiarize oneself with the technicalities of the model in Cooper, Seiford and Tone (2007, pp. 99-106), wherein he will find its exhaustive description.

The employment of the SBM model presents an additional value added of this paper as follows from the overview of some previous studies as summarized in Section 2. Other studies restricted themselves to using oriented DEA models solely (to wit the CCR model as well as the BCC model) under the implicit assumption that banking inputs and outputs are proportionally scalable (and thus radial). This model possesses an important property, which is that it allows slack of inputs and outputs to be non-radial.

\section{The assumption of the production frontier time invariance during three identified phases of the Slovak banking sector development}

Every sensible and interpretable application of the DEA rests on the explicit assumption of the existence of a production frontier that delimits the set of all disposable inputs and attainable outputs. The optimization task of a chosen DEA model then constructs in a non-parametric fashion the production frontier and measures in an appropriate way the distance of individual production units from the production frontier and captures it in the form of a score (used in assessing the relative efficiency of a given production unit and in the benchmarking). However, it often happens that the production frontier changes over time (even this change is required for the theory of economic growth to be valid and hold). However, in some consecutive periods the production frontier due to the inertia of the economic environment may remain invariant, that is, invariant with respect to a time shift. This view is applied in the paper and it is believed that there are some phases in the evolution of the Slovak banking sector during which its production frontier remained intact and free of shift. During the period from 2000 to 2011, three sub-periods can be identified and justified: 2000-2003, 20042008, 2009-2011.

- The first phase (2000 to 2003) reflects the last quivers of the restructuralization of major banks and of the privatization of selected banks in the Slovak Republic that commenced in the 1990s. Whereas political decisions on the transfer of illiquid assets into a specialized state institution were taken in the second half of the 1990's and the transfer itself took place especially in the years 1998 and 1999, the cleaning-up of balance sheets of the Slovak major banks ended only at the beginning of the 2000s. The privatization of banks in the Slovak Republic that was started by an entry of the Austrian group Erste Bank into Slovenská sporitel'ña in January 2001 and continued by 
other acquisitions resulted in the integration of the Slovak banking sector into the global banking system due to its property relations with the largest European banking groups. This phase was also accompanied by final stages of the transformation process of the Slovak economy.

- The second phase (2004-2008) begins by the accession of the Slovak Republic into the European Union and terminates by the entry of the Slovak Republic into the euro area. Slovak banks during this period implemented a new system of corporate governance, moved to communication with targeted client segments and towards electronic banking services. There were significant changes in balance sheet and off-balance sheet operations, in the structure of services and in the orientation on investment banking, mortgage banking as well as asset management. In the years 2006-2008 Slovak banks were intensively engaged in the preparations for the entry of the Slovak Republic into the euro area as of 1 January 2009.

- The third phase (2009-2011) is marked by the successful adaptation of the Slovak banking sector to the euro environment and by the manifestations of the economic crisis in the Slovak economy. Thanks to commercial banks as well, the process of the euro-conversion was smooth and trouble-free. On the other hand, of impact on the Slovak banking sector was the global economic crises that brought about a dramatic fall in the economic growth of the Slovak Republic. Small Slovak banks faced existence problems.

Evidence that the Slovak banking sector did manifest substantial qualitative changes between these three sub-periods results from a previous research endeavour accomplished by the authors. Under the set-up of generalized additive modelling and in a Cobb-Douglasian framework of stochastic frontier analysis (SFA), Bod'a and Zimková (2013) showed in their paper, from somewhat a different angle, that there were changes present in the development of the Slovak banking sector during the three identified stages. Using statistical methods, it was found a priori regardless of economic reasoning that the Slovak banking sector experienced changes of its production technology, and these findings are compatible with the outline and justification presented afore.

\section{Data and results}

In this section, the selection of organizational units of the Slovak banking sector and the selection of a particular set of inputs and outputs are clarified and explained. After this introductory part of the section, the results are presented in an organized way.

The dataset comprises the data on 11 organizational units (commercial banks) operating in the Slovak Republic and it covers the great majority of Slovak banking structures (as the total of included banks exceeds 90 percent of the 
Slovak banking assets). The organizational units considered in the paper are listed in Table 2. In order to assure consistency of the analysis, building societies and special financial institutions are subject to exclusion. The source of the data is TREND Holding, s.r.o., Bratislava.

Table 2 Organizational units of the Slovak banking sector subjected to the analysis

\begin{tabular}{c}
\hline Organizational unit \\
\hline \hline Citibank Europe plc, foreign bank subsidiary (before 2009 Citibank (Slovakia), a. s.) \\
\hline Československá obchodná banka, a. s. (in 2009 merged with Istrobanka, a. s.) \\
\hline Prima banka Slovensko, a. s. (before 2011: Dexia banka Slovensko, a. s.) \\
\hline Privatbanka, a.s. (before 2005 Banka Slovakia, a. s.) \\
\hline OTP Banka Slovensko, a. s. \\
\hline Sloventová banka, a.s. \\
\hline VOLKSBá sporitelňa, a. s. \\
\hline UniCredit Bank Slovensko, a. s. (since 2013 Sberbank Slovensko, a. s.) \\
\hline Všeobecná úverová banka, a. s. \\
\hline
\end{tabular}

Source: The authors

The data used in the empirical analysis are the yearly data of balance-sheet items disclosed by the eleven organizational units of the Slovak banking sector during the period 2000-2011. During the period some of the organizational units underwent a merger or a takeover, it was therefore necessary to operate with totals on the banks which changed its legal and economic status. The data on these banks were aggregated as a total and only the merger or the acquisitor was considered. The hypothesis on the time-invariance of the production function permitted the pooling of individual organizational units in the identified phases and resulted in "bank-years". Only the data for 4 bank-years were not complete (ČSOB / Istrobanka 2007 \& Citibank 2009, 2010, 2011). In consequence, the first phase was represented by $11 \times 4=44$ bank-years, the second phase included 11 $\times 5-1=54$ bank-years, and finally, the third phase was formed by $11 \times 4-3=$ 41 available bank-years. The data are evaluated within the framework of DEA separately; in other words, the DEA was conducted for each of the three phases independently.

Only one input and only one output are recognized in the study. The input selected under the profit approach is total operating expenses and the output to be maximized is represented by net interest income. Both production variables represent singular items that appear on profit and loss statements of commercial banks and are always disclosed under any reporting standards. Operating expenses are the expenses incurred in conducting banking operations that are composed of interest payments made on the banks' liabilities (especially deposits), costs of running the banks' operations (such as wages, rental costs, 
servicing costs or purchases of inventory) and provisions for loan losses. Net interest income labels the gross interest income less gross interest expense of the bank. Both indicators selected for the analysis are traditional indicators on the footing of which the banking performance is assessed (see Mishkin, 2007, pp. 3436; Koch and MacDonald, 2010, pp. 86-91). This is due to the fact that profit and loss statements of commercial banks reflect the financial nature of banking, as interest on loans and investments represents the bulk of revenue. In addition, the variation of net interest income permits an assessment of the ability of the banks' management to control interest rate risk. As a matter of fact, the production variables used in this study are reported in compliance with International Accounting Standards / International Financial Reporting Standards (IAS/IFRS).

The pooling of the data from different years necessitated their deflation for a proper analysis. Individual data were deflated to the prices of 2000 by the GDP deflator provided by Eurostat.

In the paper, the role of production units is undertook by individual organizational units in the Slovak banking sector in the three phases of its development. Three runs of the SBM analysis were made with (the number of inputs) $m=1$ and (the number of outputs) $s=1$, one for each phase. In the first phase, the number of decision making units was $n=44$, in the second phase, $n=54$, whilst in the third phase, $n=30$.

All computations were performed in the program $R$ ( $R$ Development Core Team, 2013) by means of functionalities included in package nonparaeff (Oh and Suh, 2013). The results are displayed compactly in Table 3; which presents the information on the achieved SBM score for each organizational unit of the Slovak banking sector in each phase. The (simplifying if understandable) designations of individual organizational units indicated in the table are also used in the interpretations.

Each sub-period subjected to the analysis represents a structurally different quality of the economic environment, in which commercial banks pursue their goals and undertake their business activities. This fact is entertained in the subsequent economic interpretations of the results obtained. Whilst the first subperiod (2000 to 2003) is the ending phase in the restructuralization and privatization of the Slovak banking sector and is marked with the introduction of the foreign corporate governance in the area of banking, the second sub-period (2004-2008) is heavily influenced with the accession of the Slovak Republic to the European Union in 2004 and is characteristic of a dynamic economic growth as well as an increasing offer of banking services. Eventually, the third sub-period (2009-2011) delimits itself with the onset of the financial crisis and goes into an economic downturn. 
Table 3 Results of the application of the SBM model in the individual phases

\begin{tabular}{|c|c|c|c|c|c|c|c|c|c|c|c|}
\hline \multicolumn{2}{|c|}{ FIRST PHASE } & \multicolumn{2}{|c|}{ SECOND PHASE } & \multicolumn{2}{|c|}{ THIRD PHASE } & \multicolumn{2}{|c|}{ FIRST PHASE } & \multicolumn{2}{|c|}{ SECOND PHASE } & \multicolumn{2}{|c|}{ THIRD PHASE } \\
\hline YEAR & SCORE & YEAR & SCORE & YEAR & SCORE & YEAR & SCORE & YEAR & SCORE & YEAR & SCORE \\
\hline \multicolumn{6}{|c|}{ Citibank } & \multicolumn{6}{|c|}{ ČSOB / Istrobanka } \\
\hline 2000 & 0.694 & 2004 & 0.778 & 2009 & NA & 2000 & 0.929 & 2004 & 0.744 & 2009 & 0.602 \\
\hline 2001 & 0.848 & 2005 & 0.596 & 2010 & NA & 2001 & 0.755 & 2005 & 0.452 & 2010 & 0.512 \\
\hline 2002 & 0.907 & 2006 & 0.552 & 2011 & NA & 2002 & 0.655 & 2006 & 0.623 & 2011 & 0.467 \\
\hline 2003 & 0.687 & 2007 & 0.669 & --- & --- & 2003 & 0.886 & 2007 & 0.769 & --- & --- \\
\hline--- & --- & 2008 & 0.856 & -- & $\cdots$ & --- & --- & 2008 & NA & --- & $--\cdot$ \\
\hline \multicolumn{6}{|c|}{ OTP Banka Slovensko } & \multicolumn{6}{|c|}{ Poštová banka } \\
\hline 2000 & 0.151 & 2004 & 0.594 & 2009 & 0.483 & 2000 & 0.357 & 2004 & 0.656 & 2009 & 0.628 \\
\hline 2001 & 0.475 & 2005 & 0.644 & 2010 & 0.486 & 2001 & 0.379 & 2005 & 0.462 & 2010 & 0.74 \\
\hline 2002 & 0.41 & 2006 & 0.727 & 2011 & 0.468 & 2002 & 0.665 & 2006 & 0.671 & 2011 & 1 \\
\hline 2003 & 0.496 & 2007 & 0.723 & --- & --- & 2003 & 0.533 & 2007 & 0.776 & --- & --- \\
\hline--- & --- & 2008 & 0.768 & --- & $\cdots$ & --- & --- & 2008 & 0.841 & --- & --- \\
\hline \multicolumn{6}{|c|}{ Prima banka } & \multicolumn{6}{|c|}{ Privat banka } \\
\hline 2000 & 0.889 & 2004 & 0.808 & 2009 & 0.341 & 2000 & 0.931 & 2004 & 1 & 2009 & 1 \\
\hline 2001 & 0.836 & 2005 & 0.626 & 2010 & 0.357 & 2001 & 0.767 & 2005 & 0.752 & 2010 & 0.674 \\
\hline 2002 & 1 & 2006 & 0.882 & 2011 & 0.384 & 2002 & 1 & 2006 & 0.966 & 2011 & 0.727 \\
\hline 2003 & 0.85 & 2007 & 0.853 & --- & --- & 2003 & 0.918 & 2007 & 0.869 & --- & --- \\
\hline--- & -- & 2008 & 0.817 & --- & -- & -- & --- & 2008 & 1 & --- & -- \\
\hline \multicolumn{6}{|c|}{ Slovenská sporitel'ňa } & \multicolumn{6}{|c|}{ Tatra banka } \\
\hline 2000 & 0.826 & 2004 & 0.798 & 2009 & 0.797 & 2000 & 1 & 2004 & 0.817 & 2009 & 0.573 \\
\hline 2001 & 0.829 & 2005 & 0.77 & 2010 & 0.988 & 2001 & 0.79 & 2005 & 0.754 & 2010 & 0.617 \\
\hline 2002 & 1 & 2006 & 0.871 & 2011 & 1 & 2002 & 1 & 2006 & 0.744 & 2011 & 0.673 \\
\hline 2003 & 0.939 & 2007 & 0.979 & --- & --- & 2003 & 0.735 & 2007 & 0.681 & --- & --- \\
\hline--- & --- & 2008 & 1 & --- & -- & --- & --- & 2008 & 0.708 & --- & --- \\
\hline \multicolumn{6}{|c|}{ UniCredit Bank } & \multicolumn{6}{|c|}{ VOLKSBANK Slovensko } \\
\hline 2000 & 0.744 & 2004 & 0.749 & 2009 & 0.401 & 2000 & 0.705 & 2004 & 0.649 & 2009 & 0.351 \\
\hline 2001 & 0.7 & 2005 & 0.622 & 2010 & 0.401 & 2001 & 0.633 & 2005 & 0.654 & 2010 & 0.398 \\
\hline 2002 & 0.967 & 2006 & 0.878 & 2011 & 0.452 & 2002 & 0.687 & 2006 & 0.711 & 2011 & 0.388 \\
\hline 2003 & 0.657 & 2007 & 0.873 & --- & --- & 2003 & 0.685 & 2007 & 0.653 & --- & --- \\
\hline--- & --- & 2008 & 0.894 & --- & -- & --- & --- & 2008 & 0.714 & --- & --- \\
\hline \multicolumn{12}{|c|}{ Všeobecná úverová banka } \\
\hline & & & 2000 & 0.704 & 2004 & 0.878 & 2009 & 0.853 & & & \\
\hline & & & 2001 & 0.831 & 2005 & 0.849 & 2010 & 0.901 & & & \\
\hline & & & 2002 & 0.799 & 2006 & 0.848 & 2011 & 0.94 & & & \\
\hline & & & 2003 & 0.855 & 2007 & 0.931 & --- & --- & & & \\
\hline & & & --- & --- & 2008 & 1 & -- & --- & & & \\
\hline
\end{tabular}

Source: The authors

The results of SBM technical efficiency scores for individual sub-periods are reproduced for convenience graphically in Figures 1,2 and 3. Individual scores are marked with red asterisks and their arithmetic average for each sub-period and for each of eleven organizational units of the Slovak banking sector are displayed by the black triangle. 
Figure 1 SBM technical efficiency scores for individual banks in the first sub-period

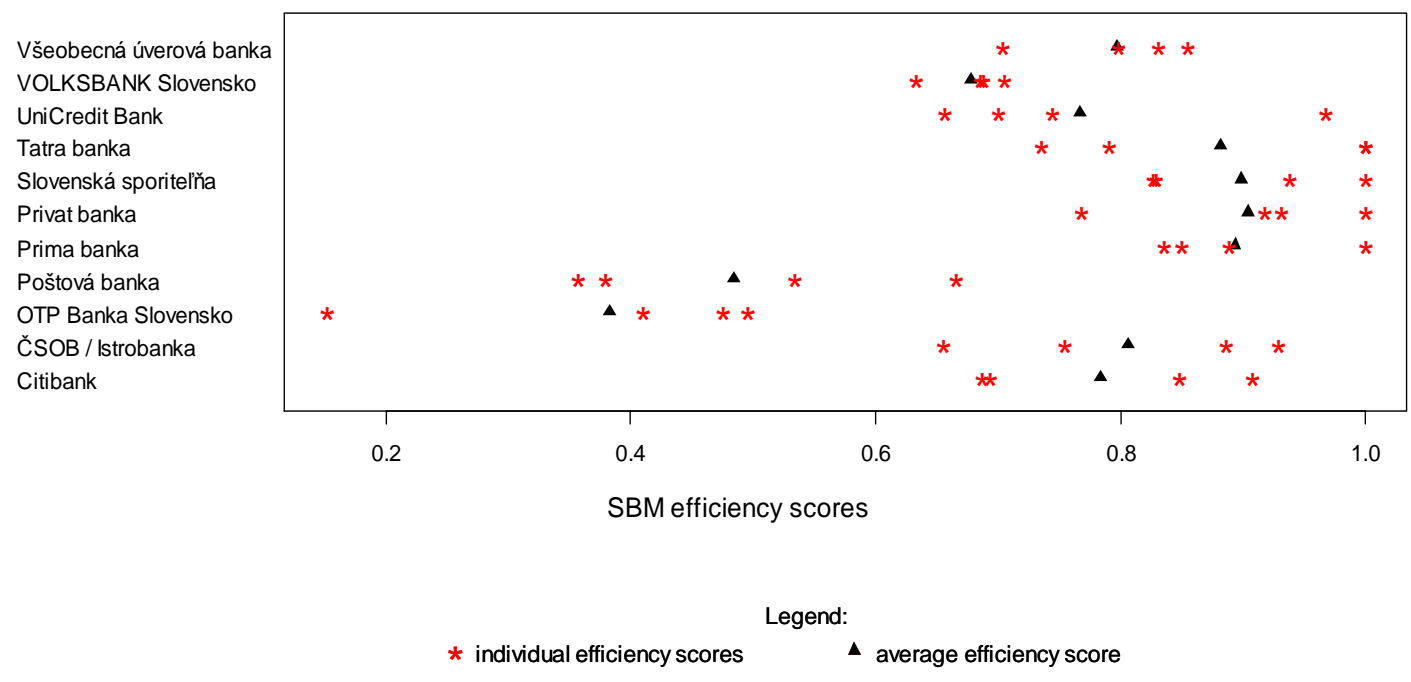

Source: the authors

Figure 2 SBM technical efficiency scores for individual banks in the second sub-period

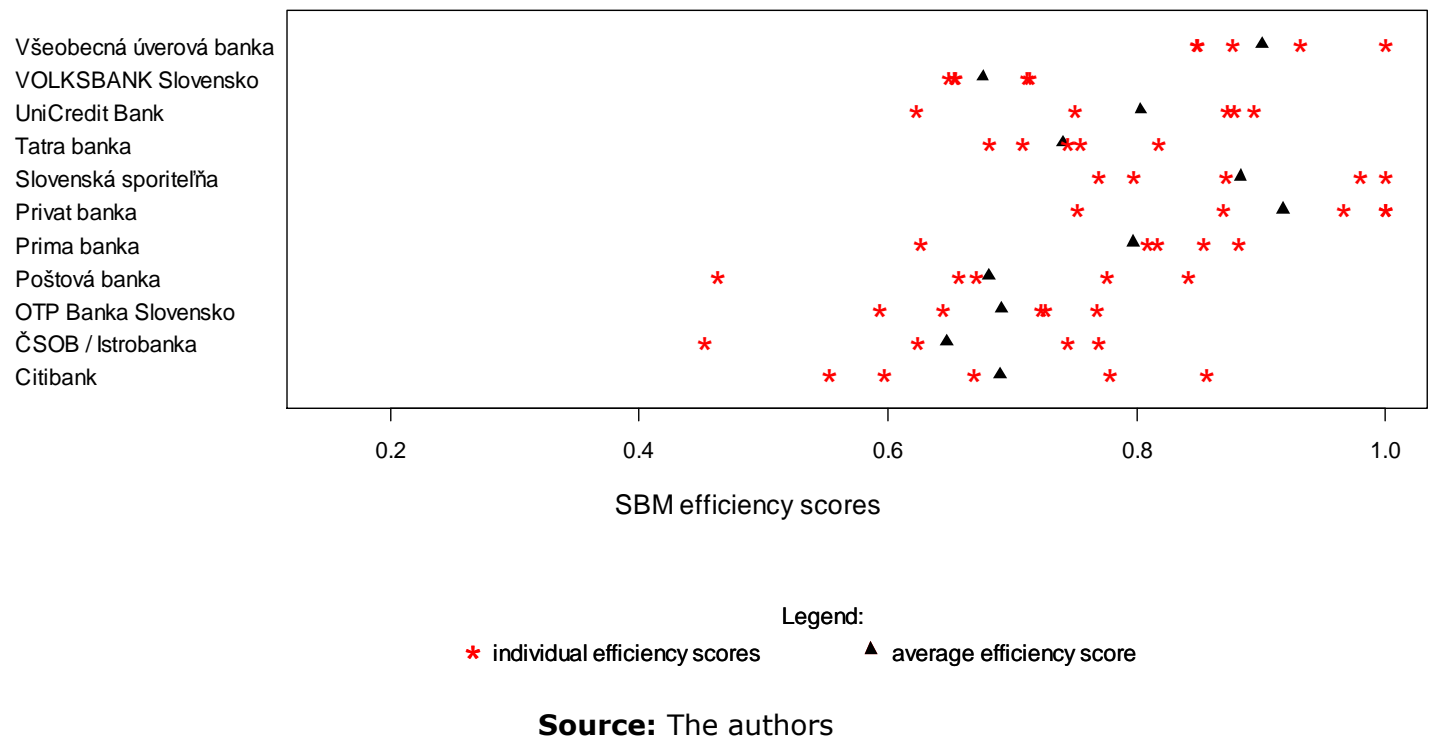


Figure 3 SBM technical efficiency scores for individual banks in the third sub-period

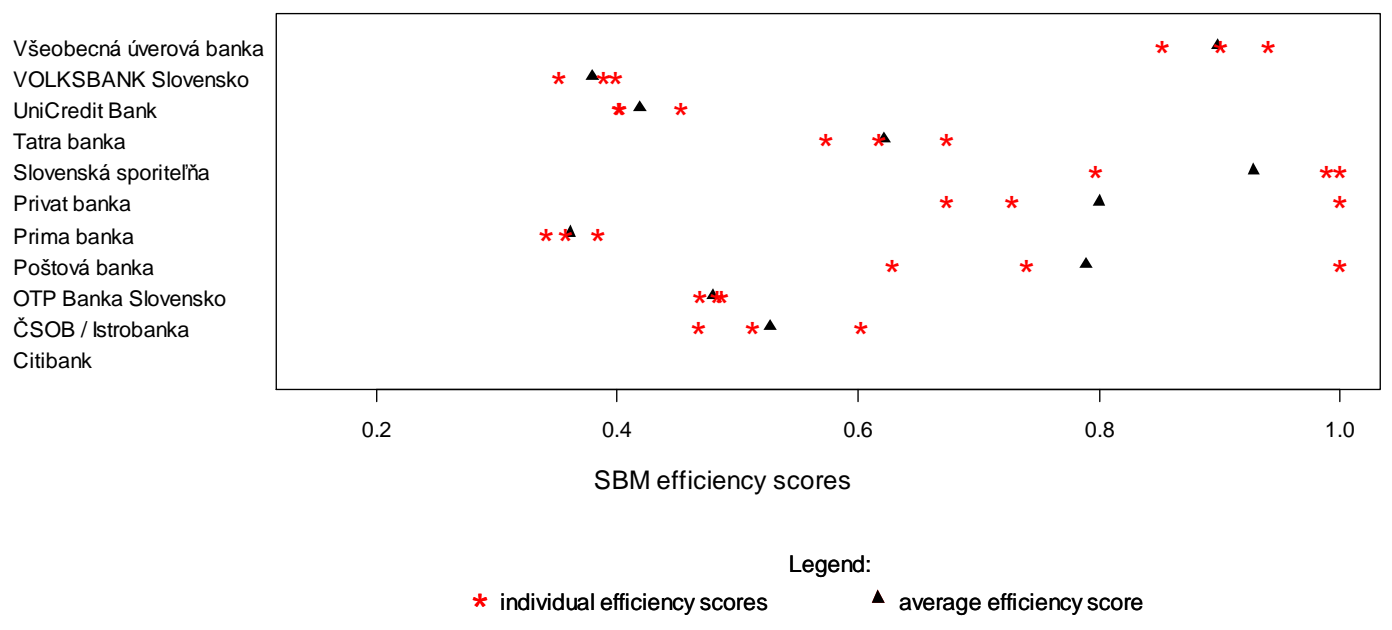

Source: The authors

The application of the SBM model in league with the profit concept of banking efficiency resulted in the knowledge that the number of full technically efficient organizational units of the Slovak banking sector relatively oscillated over the identified three phases. Whilst in the first sub-period, a total of four banks were found technically efficient in any year of the given sub-period (i. e. Prima banka, Privat banka, Slovenská sporitel'ña and twice Tatra banka), only three banks were found technically efficient for the second sub-period (twice Privat banka, Slovenská sporitelňa and Všeobecná úverová banka) as well as for the third subperiod (Poštová banka, Privat banka and Slovenská sporitelña). The pattern of technical efficiency in individual sub-periods is aptly captured by the preceding Figures 1,2 and 3.

- In the first sub-period of 2000-2003, Poštová banka and OTP banka Slovensko were clearly least technically efficient in the Slovak banking sector, of course, on a comparative basis and with respect to the profit approach of efficiency. Both of these banks are retail banks. On the other hand, comparatively most efficient banks are obviously two wholesale banks Slovenská sporitel'ña and Tatra banka, and two retail banks Prima banka and Privat banka. Another wholesale banka, Všeobecná úverová banka, in the first sub-period can be classified as a mediocre banks with respect to its profit efficiency. The largest Slovak commercial bank, Slovenská sporitelña, attained technical efficiency in 2002, a year after the government cleared the last remains of illiquid assets off its portfolio. Tatra banka manifested technical efficiency in two years, 2000 and 2002, even without governmental assistance. The comparative efficiency of privatized commercial banks may be 
attributed to new corporate governance and to the promising economic growth of the Slovak economy.

- The second sub-period of 2004-2008 brought about some changes in the efficiency pattern of the Slovak banking sector. SBM efficiency scores are seemingly somewhat higher than in the previous sub-period (nonetheless, this can by no means be interpreted as an improvement in the overall efficiency). Three organizational units are comparatively more efficient during this second phase of the development of the Slovak banking sector, two of them are wholesale banks (Všeobecná úverová banka, Slovenská sporitelňna) and one of them is a retail bank (Privat banka). In plain words, Slovenská sporitel'ña and Privat banka retained in the second sub-period the status of benchmark in technical efficiency. None of the organizational units manifested considerably lower SBM efficiency scores and individual banks form a coherent group when comparing their operating expenses and interest income. This can be possibly attributed to the fact that - during this subperiod - the real Slovak economy underwent a dynamic growth path and commercial banks started to extend the supply of their services especially with asset management, leasing, structural products. This is consistent with their ambitions of profit maximization in the good times of the Slovak economy.

- Obviously, a most heterogeneous distribution of efficiency in the Slovak banking sector is found in the third sub-period of 2009-2011. During this stage, two organizational units (i.e., Privat banka and Poštová banka) may have had attained full technical efficiency in one year, but their average efficiency performance is ordinary on a comparative footing. A high efficiency profile was maintained by two wholesale banks (Slovenská sporitelńna and Všeobecná úverová banka) and this contrasts with other three small banks (VOLKSBANK Slovensko, Prima banka, UniCredit bank) whose efficiency scores were uniformly low during the sub-period under the evaluation. All of these three organizational units were, during this sub-period or later, subject to changes in ownership relationships. Another aspect of the changes between the two consecutive sub-periods is that the comparative efficiency status of Privat banka slightly worsened and this bank no longer exhibited a high efficiency profile held in the previous two sub-periods. Similar is true e. g. for UniCredit Bank, and the reverse holds e. g. for Poštová banka. It is also of interest that the technical efficiency of Prima banka rapidly declined during the identified three sub-periods, and Tatra banka is characteristic of a gradual decline in its efficiency status. 


\section{Conclusions}

This paper represents a case study, in which organizational units of the Slovak banking sector over the years 2000-2011 are evaluated in terms of technical efficiency that they exhibit in their operations from the standpoint of the profit approach. The results gained in the analysis are not an end in themselves but are weighty for several reasons and useful to several subjects. First and foremost, the results are applicable for a subsequent analysis of the corporate banking strategy that has been pursued in the Slovak banking sector over the period of few past years. From this aspect, it gives an opportunity to regulatory bodies to evaluate corporate banking strategy in retrospect from the viewpoint of technical efficiency. Secondly and with no lesser importance, it provides needful information for stockholders and management of commercial banks so that they may be able to form perspectives of the future banking strategy, again with respect to technical efficiency. Technical efficiency status changes and evolves over time and is influenced by a number of factors from the inner and outer environment of individual commercial banks.

In the evaluation, a non-parametric SBM model was applied and therein lies another added value of the contribution. In methodology, the study enriches the existing literature with the possibility of using the SBM model of DEA. Previous studies that examined technical efficiency of commercial banks operating in the territory of the Slovak Republic and abroad contented themselves with using merely basic and (furthermore) oriented DEA models (to wit, the CCR model and the BCC model). However, these two standard DEA models are both oriented and radial. The former property places a restriction that they require of the user to make a fundamental specification as to whether production units are able primarily either to control (i.e. decrease) their inputs or to control (i.e. increase) their outputs. Frequently and clearly, this is a limitation of their use in many practical situations. In addition, the latter property rests with the technical and essential assumption that production inputs and outputs are proportionally scalable (and thus radial). Contrary to this, the SBM model can be formulated non-oriented (with preference given to neither inputs nor outputs) and allows non-radial input and output slacks.

Another distinctive feature of the contribution in comparison to the previous research in the field is the specification of a model that founds itself upon the profit approach. This approach to banking efficiency was established by Berger and Mester (2003) and construes the bank as the centre of value creation. It has been customary for former studies into technical efficiency of commercial banks to approach efficiency from the standpoint of banking production or banking intermediation. In models of the production approach developed by Benston (1965) banks are viewed as economic entities that utilize labour and capital to produce deposits and loans. Under this treatment, in which inputs are measured in physical units and not in monetary units, two major shortcomings may be 
identified. It does not characterize the bank as a financial intermediary and does not make allowance for interest expenses that are usually the most substantial component of the bank's costs. In contrast, the intermediation approach proposed by Sealey and Lindley (1977) interprets deposits as a legitimate banking resource that is transformed during banking production into loans. It is the intermediation approach and its modifications that have been used most often to date in analyzing technical efficiency of commercial banks with operations settled in the territory of the Slovak Republic and of Europe. Unlike traditional approaches, the profit approach considered here in the paper pays regard to the most substantial items in costs of the commercial bank, on the input side, and includes the substantial items of profits of commercial banks operating in the territory of the Slovak Republic, on the output side. Besides, this approach also takes under advisement the intermediation function of commercial banks.

The evaluation of technical efficiency via the non-parametric SBM was conducted on two crucial assumptions. The assumption of variable returns to scale is one of classical assumptions made in such analyses, and this assumption is supplemented here by the requirement that the production frontier remain constant in three identified sub-periods (phases) in the evolution of the Slovak banking sector: 2000-2003, 2004-2008 and 2009-2011. In each of these subperiods, organizational units of the Slovak banking sector were pooled in one data frame, from which the information on the shape of the production frontier (constant in individual sub-periods and common to all organizational units in the given sub-period) was extracted by the SBM model in the form of SBM technical efficiency scores.

The division of the researched time period of twelve years into the three subperiods, during which the banking in the Slovak Republic underwent qualitative changes made it possible to characterize the situation in technical efficiency of commercial banks from the perspective of the profit approach. In the first subperiod (2000-2003), after the privatization epoch, principles of corporate governance were gradually built into the Slovak banking sector, and Slovak banks gradually learned how to operate under the conditions of a market environment. In this phase the source of profit was in particular operational bank loans. This is the reason, for which Poštová banka seems most technically inefficient in the first phase since it is oriented on retail clientele. Another most technically inefficient bank is OTP bank, which focused in this phase on financing agricultural enterprises exposed fully to transformation difficulties. On the whole, most technically efficient from the standpoint of the profit approach was Slovenská sporitel'ña whose position was achieved by means of financial governmental assistance within the restructuralization in the pre-privatization epoch. Tatra banka, Privat banka and Prima banka manifested a comparatively higher level of technical efficiency in the first sub-period even without governmental aid. In the second investigated sub-period (2004-2008) commercial banks in the Slovak Republic generated profits in a quickly developing environment of mortgage 
banking but also of newly-arisen investment banking. Financial results of Slovak commercial banks were heavily influenced by the rapid economic growth of the Slovak Republic and by a number of new aggressive strategies of their foreign owners. In this second phase, a comparatively highest level of technical efficiency was defended by Privat banka and Slovenská sporitel'ňa, which were joined as Všeobecná úverová banka. This bank started to show a higher degree of technical efficiency from the perspective of the profit approach. Finally, in the third analyzed sub-period (2009-2011) brought along the most heterogeneous results as far as technical efficiency of commercial banks with respect to the profit approach is considered. They were affected by the entry of the Slovak Republic to the eurozone as of 1 January 2009 and by the worldwide financial crisis. Both these factors pressed on technical efficiency of Slovak banks. As far as the first factor is considered, their costs considerably increased in connection to alterations and modifications in their information systems, their revenues from foreign exchange operations somewhat dropped and also revenues from servicing the cross-border payment system as the fees were unified by Single European Payment Area (SEPA) regulations. The second factor reflected itself in a decrement in investment possibilities and loan amounts provided. In consequence of these factors, higher technical efficiency under the profit approach remained to be held by Slovenská sporitel'ña concentrating upon classical banking and not upon investment one. Contrariwise, Prima banka faced existence problems due to its financial losses coming from wrong decisions in the field of investment banking and needed to go through a takeover. Similarly, Privat banka after failures with their investment businesses was found to lower its technical efficiency through the prism of the profit approach.

All this information is of note to stockholders and management of commercial banks, especially to the stockholders and the management of the banks whose technical efficiency was subject to investigation in this study. This information is necessary for them as it enables them to confront "their" commercial bank in terms of profit-oriented technical efficiency with other commercial banks operating in the Slovak Republic. The results give an insight into profit creation and explain how the substantial component of profits of Slovak commercial banks has been generated over the past few years.

\section{Acknowledgments}

The authors wish to express their gratitude to two anonymous reviewers whose comments contributed to an improvement of the final text, and are thankful to Professor Emmanuel Thanassoulis of Aston Business School for his worthy remarks and guidance.

The paper is prepared under the ægis of the grant scheme VEGA No. 1/0967/11 Innovative approaches to the system of corporate performance evaluation and under the project ITMS 26110230082 Mobility - Support of Science, Research 
and Education at Matej Bel University in Banská Bystrica (Mobility - podpora vedy, výskumu a vzdelávania na UMB) within the bounds of financial subsidy contract No. 018/2012/1.2/OPV. Also the financial support of the grant scheme VEGA No. $1 / 1276 / 12$ Dynamics of macroeconomic processes in open economies is kindly appreciated.

\section{References}

Anayiotos, G., Toroyan, H., Vamvakidis, A. (2010). The efficiency of emerging Europe's banking sector before and after the recent economic crisis. Financial Theory and Practice, vol. 34, iss. 3, pp. 247-267.

Benston, G. (1965). Branch banking and economies of scale. Journal of Finance, vol. 20 , no. 2 , pp. 312-331.

Berger, A. N., Hanweck, G. A., Humphrey, D. B. (1987). Competitive viability in banking: Scale, Scope and Product Mix Economies. Journal of Monetary Economics, vol. 20, pp 501-520.

Berger, A. N., Humphrey, D. B. (1997). Efficiency of financial institutions: international survey and directions for future research. European Journal of Operational Research, vol. 98, number 2, pp. 175-212.

Berger, A. N., Mester, L. (2003). Explaining the dramatic changes in performance of US banks: Technological change, deregulation, and dynamic changes in competition. Journal of Financial Intermediation, vol. 12, pp. 57-95.

Bod'a, M., Zimková, E. (2013). A Cobb-Douglasian production function of the Slovak banking sector under the intermediation approach. Financial management of firms and financial institutions. Ostrava: Ekonomická fakulta Vysoké školy báňské - Technické univerzity Ostrava, pp. 54-63.

Cooper, W. W., Seiford, L. M., Tone, K. (2007). Data envelopment analysis. New York: Springer, 2007.

Grigorian, D., Manole, V. (2002). Determinants of commercial bank performance in transition: an application of data envelopment analysis. Working Paper No. 146. Washington: International Monetary Fund.

Kenjegalieva, K. A., Simper, R., Weyman-Jones, T. G. (2009). Efficiency in transition banks: inter-country banking industry trends. Applied Financial Economics. vol. 19, pp. 1531-1546.

Koch, T. W., MacDonald, S. S. (2010). Bank management. 7th ed. Mason (OH, USA): South-Western.

Mishkin, F. S. (2007). Economics of money, banking and financial markets. 8th ed. Upper Saddle River (NJ, USA): Prentice-Hall, 2007. 
Oh, D.-H., Suh, D. (2013) nonparaeff: nonparametric methods for measuring efficiency and productivity, $\mathrm{R}$ package, version $0.5-8$ of 2013-02-22, http://cran.r-project.org/web/ packages/nonparaeff/index.html.

R Development Core Team (2013). R: a language and environment for statistical computing. Vienna: $\mathrm{R}$ Foundation for Statistical Computing, http://www.rproject.org/.

Sealey, C. W., Lindley, J. T. (1977), Inputs, outputs and a theory of production and cost at depository financial institutions. Journal of Finance, vol. 32, no. 8, pp. 1251-1266.

Stavárek, D., Řepková, I. (2012). Efficiency in the Czech banking industry: A nonparametric approach. Acta Universitatis Agriculturae et Silviculturae Mendeleianae Brunensis, vol. LX, number 2, pp. 357-366.

Stavárek, D. (2006). Banking efficiency in the context of European integration. Eastern European Economics, vol. 44, number 4, pp. 5-31.

Tomova, M. (2006). X-efficiency of European banking - inequality and convergence. Free University of Brussels.

Vincová, K. (2006). Neefektívnost' z rozsahu v bankovom sektore. Komparácia slovenského a českého bankového sektora. In Národná a regionálna ekonomika VI, Herlany. Košice: Technická univerzita v Košiciach, pp. 440-445.

Wozniewska, G. (2008). Methods of measuring the efficiency of commercial banks: an example of Polish banks. Ekonomika, number 84, pp. 81-91.

Zemanová, V. (2007). Aplikácia metódy DEA na bankový sektor Slovenskej republiky. In Proceedings from the conference AIESA Mladá veda 2007. Bratislava: Ekonóm. 